\title{
"I discovered race in America and it fascinated me": Alienation, Exile and the Discovery of Cultures in Chimamanda Ngozi Adichie's Americanah
}

\author{
Ali Rezaie \\ Southern University and A\&M college
}

\begin{abstract}
Depicting the economic and cultural problems facing its Nigerian immigrant protagonists, Chimamanda Ngozi Adichie's novel, Americanah provides a great opportunity for its readers to understand the increasing appeal of the idea of cultures among immigrants in the West. It shows how the problems accompanying cultural dislocation compel even alienated individuals who previously idealized the West to embrace their cultures and move away from universal and individualistic perspectives such as liberalism. Cultural dislocation not only helps immigrants discover the importance and particularity of their own culture but also the continuing influence of cultures in the West. Further complicating the picture, however, the novel also reveals how the culture discovered by immigrants in exile is distinctly different from the culture lived and understood by their counterparts in their native country. By frankly depicting both the cultural problems facing African immigrants in a racialized America and the prevalence and negative effects of Eurocentric cultural alienation among non-Western youth, Americanah helps us understand the surprising turn to cultures and away from liberalism at the start of the twenty-first century. ${ }^{1}$
\end{abstract}

1 As Raymond Williams notes in Key Words: A Vocabulary of Culture and Society, "Culture is one of the two or three most complicated words in the English language" (87). However, for the purposes of this article, I define culture, inevitably vaguely, as a particular way of life and important shaper of individual identities of a group of people inhabiting a particular geographic area or place that is constituted by important elements such as a particular language, religion, ethnicity, history, customs and traditions. I contrast this bounded and particular conception of group identity derived from a particular culture with liberalism 
Keywords: Alienation; Exile; Cultural/racial identity; Eurocentrism; Inferiority Complex, Liberalism

The prevailing discourse on Eurocentrism and, by extension American cultural imperialism, often focuses on unearthing and critiquing the disparaging perceptions of non-Western cultures in the West. While this is important, it leaves out a key aspect of Eurocentrism that is not as often explicitly acknowledged: the prevalence of internalized Eurocentrism in many non-Western societies. The global hegemony of the West in the past few centuries coupled with the chronic political, economic, and social problems in many postcolonial and non-Western countries in the global South has given currency to Eurocentric notions regarding the superiority of the West and its culture among many people in non-Western societies. Dazzled by the glamorized images of the West disseminated by the mass media and despondent about the future in their society, many in non-Western societies, especially the youth, unwittingly develop an insidious form of cultural and even racialized inferiority complex that idealizes Europe and Europeans, while denigrating non-Western cultures and peoples. ${ }^{2}$

Having despaired of their "oppressive" and "backward" cultures and so-

which, in my usage, refers to a universal and individualistic perspective derived from Enlightenment that stresses individual choice and freedom and views cultures and collective customs and traditions as, at best, secondary and unimportant in shaping individual identities and, at worst, as vestiges of a backward and bygone way of life that stand in the way of progress and individual authenticity. For a critique of liberalism and a philosophical explanation of the differences between culture and liberalism, see Charles Taylor's “The Politics of Recognition." Philosophical Arguments. Cambridge, MA: Harvard UP, 1995. 225-256.

2 Noting the prevalence of internalized Eurocentrism among non-Western natives, in The View From Afar, Claude Levi-Strauss notes how Western anthropologists who posited the uniqueness of each culture were accused by natives of "helping to perpetuate antiquated practices, which were felt to be an obstacle to development." Natives, in sharp contrast to Western anthropologists who studied their cultures, LeviStraus notes, "seemed to have no doubts whatsoever ... about the superiority of Western culture" (28). In his article on the prevalence and deep-seated nature of "colonial mentality" and internalized racism and Eurocentrism in postcolonial Africa, specifically in postcolonial Nigeria, M. E. Ochonu explains its various manifestations such as: "buying into powerful ideas about personal worth, dignity, and prestige that have origins in racist perceptions of Africans," "the process of coveting or reenacting lifestyles, mannerisms, tastes, and fads associated with colonial and postcolonial Euro-American culture and thought," "the conscious and subconscious art of seeking validation from Euro-American or colonial institutions and locales," and finally, "a conscious or subconscious devaluation of African aesthetic or quotidian objects and a preference for their Euro-American analogues" (11). See "Looking for Race: Pigmented Pasts and Colonial Mentality in 'Non Racial' Africa" in Relating Worlds of Racism: Dehumanization, Belonging, and the Normativity of European Whiteness. 
cieties, alienated non-Western youths yearn for the freedom of choice and opportunities that they believe is available in the West. This alienated state of discontent constitutes the starting point for the two immigrant protagonists of Chimamanda Ngozi Adichie's Americanah. As Adichie points out in one of her interviews, the Nigerian protagonists of Americanah, Ifemelu and Obinze, are rather atypical because they have not immigrated to the West due to war, poverty, or starvation. Rather, they idealize the West as the epitome of progress and civilization and consequently feel discontented with their lives in their native country.

I think the immigration story that we are very familiar with, when it concerns Africa, is the story of, you know, the person who's fleeing war or poverty, and I wanted to write about a different kind of immigration, which is the kind that I' $m$ familiar with, which is of middle-class people who are not fleeing burned villages, and who you know had ostensibly privileged lives, but who are seeking what I like to think of as choice - who want more, who think that somehow over there is more exciting, is better. For my generation it's the U.S., and I think this is probably the case for much of the world, because America has this enormous cultural power. ${ }^{3}$

However, life in the US and the UK to which the Eurocentrically alienated protagonists of Americanah migrate falls short of their idealized fantasy. Obinze who fails to legalize his status in England and is deported back to Nigeria has seen enough of the hardships, frustrations, and indignities of immigrant life to resolve that he will never try to leave Nigeria for a Western country again. Ifemelu, on the other hand, who comes to America to pursue a college degree is mostly free from the problems faced by the undocumented Obinze and succeeds in achieving upward mobility by becoming a successful and recognized blogger. Having lived in America for over thirteen years, however, Ifemelu has been unable to bridge the cultural and racial gap that separates her from the mainstream American society. This failure has only fueled her desire for returning to Nigeria where she hopes to reconnect with her Nigerian identity which she has come to rediscover and appreciate in diaspora. At the end of the novel, Ifemelu and Obinze become happily and symbolically reunited in Nigeria after a long period of separation. Americanah's celebration of its protagonists' repatriation and reintegration into their native society, as several critics have noted, 
marks it as a "new kind of immigration novel" (Austin 13) that conveys a "a carefully wrought declaration of loyalty to language, homeland, and self in an increasingly global society" (Esplin 85). Thus, the novel depicts immigration to the West not as a celebration of cultural hybridity and liberal multiculturalism but as a chance for alienated non-Western immigrants to retrieve their cultural identity from internalized Eurocentrism.

Given the increasing rates of immigration from African countries to the US in the past several decades, it is not surprising that we are witnessing a surge in works of fiction and non-fiction in English by African writers about the experiences of being an immigrant or a member of a minority in Western Europe or North America. ${ }^{4}$ Thus, Americanah is not the only novel by an African or Nigerian novelist to explore the cultural and racial problems facing African immigrants in the West and more specifically in the US. Among others, one can cite the following Anglophone novels: Ike Oguine's A Squatter's Tale, Okay Ndibe's Foreign Gods, Inc., Imbolo Mbue's Behold the Dreamers, NoViolet Bulawayo's We Need New Names, Sefi Atta's A Bit of Difference, and Teju Cole's Open City. Among these, A Squatter's Tale, Foreign Gods, Inc., We Need New Names, and Behold the Dreamers are more specifically focused on portraying the sense of cultural bereavement, isolation and alienation experienced by many immigrants. By the end of Foreign Gods, Inc., for example, the highly educated Nigerian immigrant protagonist, Ike, realizes the terrible toll he has incurred in his struggle to survive and integrate into the mainstream US society. It is after selling the purloined statue of the tribal god of his village to a New York gallery that he finds himself magically transformed into an Igbo tribal priest who has been appointed as the new guardian of their village god. Thus, the conclusion of the novel symbolically captures the sense of disappointment, guilt and cultural betrayal felt by its Nigerian immigrant protagonist whose failure in America has brought him to the brink of insanity. A Squatter's Tale also highlights the contrast between an imagined and idealized America and the real one experienced by its Nigerian immigrant protagonist. While the novel ends on an open-ended but apparently optimistic note with the protagonist feeling resolved to embark on his integration journey in the US, it, nonetheless, depicts many of the disappointments and frustrations facing

4 According to a study by the Pew Research Center, from 2000 to 2013, the population of African immigrants in the US has increased 41 percent, making this demographic group "the fastest growing immigrant community" in the US (qtd. in Taylor's "Language, Race, and Identity in Adichie's Americanah and Bulowayo's We Need New Names." 
African immigrants in the US due to undocumented status, cultural differences, and economic and professional downward mobility. In We Need New Names, the teenage immigrant protagonist, Darling, explains her ambivalence regarding her situation in the US. Although caused by her illegal status, many of Darling's discontents have to do with the anomie, alienation and loneliness that result from her cultural and racial difference in America. She is young enough to readily assimilate into the new culture and yet she is old enough to see how her Americanization jars with her continuing attachment to her homeland and its culture. Finally, in Behold the Dreamers too, we have the novel ending by its Cameroonian immigrant protagonist and his family deciding to voluntarily leave the US and return to their country. Here too, the stresses and hardships resulting from an undocumented status and the accompanying hardships prove too much for Jende who after five years of trying to legalize his status decides to return to Cameroon rather than continue his degrading and stressful life in America.

Americanah distinguishes itself from these other immigrant novels not only due to its more extensive depiction of the cultural and racial problems facing African, more specifically, Nigerian immigrants in the US and England but also because its protagonist Ifemelu has achieved the material and economic rewards that come with realizing her American dream. Thus, its depiction of the problems facing immigrants in America cannot be rejected as the sour grapes of an unsuccessful and bitter immigrant. However, as Maximilian Feldner points out in Narrating the African Diaspora, the privileges that enable Ifemelu and Obinze to permanently return to Nigeria are not typically enjoyed by many other Nigerian immigrants, as attested by the novel itself. Unlike Ifemelu, many African characters depicted in African novels about immigration must struggle with the dangers and limitations of their undocumented or illegal status. At the same time, many of these characters do not have the privileges and resources available to Obinze after his return to Nigeria "which enables him to find professional success and personal happiness" (Feldner 196). Nevertheless, by opting for these two privileged and economically secure Nigerians for its protagonists, Americanah seeks to highlight the cultural and psychological frustrations and hardships common to most non-Western immigrants, regardless of their legal and economic status. Having privileged and Westernized protagonists also allows Adichie to scrutinize the issue of Eurocentric cultural alienation in non-Western countries like Nigeria and further highlight the issue of cultures and cultural differences in our increasingly globalized world. The rediscovery and reappreciation of their particular culture in the previously 
alienated and Westernized Ifemelu and Obinze not only shows the centrality of cultures and cultural differences for immigrants but also draws attention to the problem of Eurocentric cultural alienation in non-Western societies.

Importantly, Americanah puts America in between the circular journey of its protagonist Ifemelu which starts and ends in Nigeria. To return to Nigeria with a better understanding of her own self and her cultural identity, Ifemelu needs to have experienced and struggled with the cultural and racial differences she encounters in America. It is in America that she gradually discovers her identity and understands the negative effects of her internalized Eurocentrism on her perceptions of herself and her culture. Having unsuccessfully experimented with a variety of racial and cultural identities such as assimilationist cosmopolitanism, Pan-Africanism and Nigerian-American hybridity to help cope with the anomie and loneliness that underlies her difference and minority status in the US, she finally decides to return to Nigeria.

The opening chapters of Americanah gives us a glimpse into the conditions that could have contributed to Ifemelu's alienation before immigration. Due to both the British colonial legacy of Nigeria and the diversity of its languages and ethnicities that have made English the official language of government and education in the country, Ifemelu, like many other Nigerians from educated families has been immersed in the English language and culture. English is not only the language used in school but also the language of her favorite books and novels; Ifemelu and Obinze, like many of their peers at school, are well-versed in both British and American literature. One of the favorite topics for debate between Ifemelu and Obinze is the merits and demerits of British and American literature. This is while their native language, Igbo, seems to have been declining. For example, soon after they meet, Ifemelu and Obinze test each other's proficiency in Igbo which suggests how their own language Igbo has been overshadowed by English. Not knowing more than a few Igbo traditional proverbs, Ifemelu concedes defeat to Obinze and asks him: "How do you know all that? ... Many guys won't even speak Igbo, not to mention knowing proverbs" (74). As Jack Taylor argues in her analysis of this passage, "Adichie highlights how English suppresses the identity and culture Igbo provides. Americanah gives voice to the colonial legacy of Nigeria and how a key feature of colonialism - the adoption of the colonizer's language as a tactic of colonial conquest-works to negate one's culture and refashion the colonial subject's identity" (73). At this point in the novel, Ifemelu is not 
aware how her fluid proficiency in English has contributed to her alienation from her native culture; it is later in America that she realizes that language is not simply a means of communication but rather an integral part of one's culture and identity.

Given the epidemic poverty and apparent backwardness of Nigeria in comparison to developed Western countries, the enormous appeal enjoyed by English as the language of civilized Western countries is not surprising. "I read American books because America is the future," Obinze declares to his mother (84). However, such a fetishizing view of the West implicitly or explicitly creates and consolidates a negative view of one's native and national language, culture and even people. As the Kenyan novelist Ngũgĩ wa Thiong'o observes, learning English in African countries, often, unfortunately, entails internalizing a Eurocentric worldview and inferiority complex. Reflecting on his education in Kenya, wa Thiong'o argues: "In schools and universities our Kenyan languages ... were associated with negative qualities of backwardness, underdevelopment, humiliation and punishment. We who went through that school system were meant to graduate with a hatred of [our] people and [our] culture" (28). Inattentive to the negative effects of her inferiority complex, the alienated non-Western subject works at mastering English and its literature to sever herself from her "backward" culture so that she could imagine herself on a par with superior Westerners. As Frantz Fanon states in his classic book on cultural alienation Black Skin, White Masks,

Every colonized people - in other words, every people in whose soul an inferiority complex has been created by the death and burial of its local cultural originality - finds itself face to face with the language of the civilizing nation; that is, with the culture of the mother country. The colonized is elevated above his jungle status in proportion to his adoption of the mother country's cultural standards. He becomes whiter as he renounces his blackness, his jungle. (18)

Even in a multi-ethnic society like Nigeria where individuals are likely to be acutely aware of their ethnic and cultural affiliations, Eurocentric cultural alienation could prevail because it could enable the alienated individual to view cultures and groups that are more open to the West as superior to those that are less influenced by the West. Besides, the alienated individual would not balk at viewing her culture as "backward" because she regards herself as separate from her culture and thus untainted by its "backwardness." 
Importantly, Ifemelu and Obinze belong to a less affluent but educated middle class background who unlike some of their more privileged peers cannot afford vacations and family-sponsored education in Europe and North America. ${ }^{5}$ This inability to visit the West, coupled with the dim economic prospects facing educated youth from lower middle classes in a notoriously corrupt and widely unequal Nigeria, seems to have intensified the thirst of youths like Obinze and Ifemelu for leaving Nigeria for a Western country like England or America. ${ }^{6}$ This desperation is, however, most evident in Obinze who worships America and often dreams about living in the US. Having failed like many other Nigerians at acquiring a US visa, he tags along with his mother when she goes to England for an academic conference and decides to overstay his visa and live there illegally. As Obinze explains to Ifemelu later in the novel, after becoming wealthy in Nigeria, he is no longer obsessed with America because he has realized that he "could buy [America] and [thus] it [has] lost its shine" (535-536). ${ }^{7}$ In other words, an important factor in the glamor enjoyed by West for non-Westerners is its unattainableness.

However, the closest the novel comes to acknowledging the prevalence of cultural alienation in Nigeria among the educated middle classes is when we have Obinze's reflections on his reasons for leaving Nigeria and staying illegally in England.

They [English people] would not understand why people like him, who were raised well fed and watered but mired in dissatisfaction, conditioned from birth to look towards somewhere else, eternally convinced that real lives happened in that somewhere else, were now resolved to do dangerous things, illegal things, so as to leave, none of them starving, or raped, or from burned villages, but merely hungry for choice and certainty (341).

In this quote, Obinze admits to his own cultural alienation as the main reason for his dissatisfaction with his life in Nigeria and his desperation to immigrate to Europe. Unlike less privileged or educated Nigerians, for Obinze and Ifemelu who are Eurocentrically alienated, Europe is not only

5 In his memoir, Never Look an American in the Eye, Okey Ndibe also states how he and his fellow Nigerian youth were obsessed with the UK and USA.

6 On the difficulties facing educated Nigerians, more specifically female Nigerians, amidst pandemic corruption and sexism, see Sefi Atta's novel Swallow.

7 For more on the dreamlike preoccupation of many youths in Nigeria with immigration to England or America, see chapter one in the Nigerian novelist Okay Ndibe's memoir Never Look an American in the Eye. 
attractive for the wealth it promises but also for its Civilization. They have mastered the English language and its literature to initiate themselves into the more civilized culture of the West and separate themselves from their "backward" culture.

Americanah, appropriately, provides a more elaborate depiction of the effects of Eurocentric cultural alienation in its middle sections that delineate the cultural and racial problems Ifemelu encounters in the US. It is after living in the US that Ifemelu starts to recognize the negative effects of her cultural self-alienation on her perceptions of herself and her culture. Instead of seamlessly integrating into the US society and its culture, Ifemelu becomes more aware of her difference as an African and a Nigerian. This is only surprising because as the anthropologist Roy Wagner explains, we are not, by default, appreciative of our culture and identity and of its importance in our daily lives. We need cultural dislocation and its accompanying "culture shock" for the discovery of cultures. Before cultural dislocation, Wagner argues, the person has "no culture ... since the culture in which one grows up is never really 'visible' - it is taken for granted and its assumptions are felt to be self-evident" (4). Surrounded by people who share our cultural background, we do not realize how important its distinctive features have been in making us who we are (7). Furthermore, the general tendency to downplay the importance of cultures in shaping individual identities is exacerbated in non-Western societies by the desire among alienated individuals to separate themselves from their "backward" cultures. In other words, discontented individuals in non-Western societies have more reason to dismiss cultures and cultural differences as superficial and unimportant. Nevertheless, the importance of cultures and the negative effects of internalized Eurocentric cultural alienation and inferiority complex inevitably become apparent to non-Western immigrants after they are dislocated from their culture and society.

Upon arriving in the US, Ifemelu is immediately struck by the discrepancies between her idealized vision of America and the shabby realities of the real one she has just entered. She is not only shocked by the impoverished and disheveled appearance of her Aunty Uju but also by the squalor of the streets and neighborhoods they drive through on their way from the airport. "The sweltering heat alarmed her, as did Aunty Uju's old Toyota hatchback, with a patch of rust on its side and peeling fabric on the seats. She stared at buildings and cars and signboards, all of them matte; in the landscape of her imagination, the mundane things in America were covered in a high-shine 
gloss" (127). This is reminiscent of Obi's arrival scene in A Squatter's Tale who is similarly shocked by the filth and hopelessness he witnesses in his uncle's house and neighborhood in Oakland, California. However, like Obi, Ifemelu is resolved to ignore these discrepancies and focus on integrating into America's mainstream culture.

She hungered to understand everything about America, to wear a new, knowing skin right away: to support a team at the Super Bowl, understand what a Twinkie was and what sports "lockouts" meant, measure in ounces and square feet, order a "muffin" without thinking that it was really a cake, and say "I 'scored' a deal" without feeling silly (166).

In the three-part structure of Ifemelu's cultural journey in the US, this marks the initial assimilating cosmopolitan phase. Ifemelu's bent on assimilation is above all apparent in her biracial relationship with Curt, her relaxing her hair and her determination to master the American accent. Assimilation also seems to be the path embraced by her relative, Aunty Uju who is holding multiple jobs while trying to pass the medical certification exam that would allow her to start practicing as a physician in the US. Importantly, at this point, Ifemelu, like some of her fellow African immigrants represented in the novel, seems to downplay her racial difference, and consequently distance herself from African Americans. This can be seen clearly in the class discussion in one of Ifemelu's college courses where she and a Kenyan student find themselves in opposition to African American students on censoring of the $\mathrm{N}$ word in Roots. Unlike their African American classmates, Ifemelu and Wambui state that they do not find the word offensive and thus they are against censoring it. The assimilation path, marked by a determination to become a "model minority" and thus distancing from African Americans, seems to be quite popular among many African immigrants in the US.$^{8}$ Many immigrants from Africa and the Caribbean, Adichie laments in an interview, have internalized ahistorical stereotypes of African Americans. "They don't want to be 'black," because they believe it means being "lazy." Interestingly, Adichie notes a similar change of attitude in her own views about African Americans in the same interview.

I think many black immigrants don't realize that they're able to be here and do what they're doing because of the sacrifices of African Americans. They don't know the his-

8 Among others, see Habecker, Shelly. "Not black, but Habasha: Ethiopian and Eritrean immigrants in American society.” Ethnic \& Racial Studies, 01419870, Jul2012, Vol. 35, Issue 7. 
tory. I didn't when I came. An African American man called me 'sister' once, and I was like "No, no, no. I'm not your sister. I'm not doing that." It took about a year of reading, learning and watching, for me to really come around and realize there's a context-you know, I read African American history and I'm just amazed at how recent some of the things that happened were. I'm not talking about slavery, I'm talking about 40 years ago. But when immigrants come here they absorb stories that have no context and no history. So it's "oh, black Americans are very lazy. They all live in the inner city because, you know, they don't want to work hard." Sometimes you're in a gathering of immigrants, and some of the talk can sound like you're in Alabama in 1965.

Acknowledging the tension between African immigrants in the US and African Americans, John Arthur in Invisible Sojourners attributes it to the unfamiliarity of many of African immigrants with living as a black minority in a racialized white majority society. Most African immigrants in the US, Arthur explains, come "from countries where blacks are in the majority and have responsibility for shaping their own social, cultural, political and economic destinies. As a result, the majority of Africans come to the United States with little or no understanding of the dynamics of discrimination against black Americans and people of color in general" (73). The indifference to race and lack of empathy toward the predicament of African Americans in the US shown by some African immigrants is noted by other characters in the novel as well. For example, Laura, an unsympathetic character who openly spouts denigrating and stereotypical views about African societies like Nigeria, still praises African immigrants as the model minority whose success story, according to her, disproves the race problem in the US. Later, Ifemelu is rudely reminded of the general indifference of African immigrants in the US to the race problem by Blaine's elder sister Shan who recounts how her African friend had told her that the writer of Ifemelu's blog must be "a Caribbean because Africans don't care about race" (394). The tension between African immigrants and African Americans is noted by Obi, the Nigerian immigrant protagonist of $A$ Squatter's Tale as well.

The African immigrant sometimes exhibits as much bitterness towards his AfricanAmerican cousins as the worst white racist. Confronted with scenes like those we saw during that drive through West Oakland and the terrible images of inner-city violence and despair on TV, the success-obsessed immigrant wants to get as far away as possible, psychically if not physically, from that horrible pit. He violently rejects any identification with what strikes him as irreversible disaster, the way one might disown and denounce a family member suffering from incurable alcoholism and kleptomania. It was that sort of rejection I saw on Andrew's face, that was perhaps why he took me on that tour of West Oakland - to teach me early on how to be revolted by the inner city and the AfricanAmericans who, no matter how successful some of them may become, are in our minds chained to the inner city. (29-30) 
To be sure, an important part of the assimilation path for an African, Nigerian immigrant in the US involves accent modification. Starting college, Ifemelu is shocked by the patronizing reaction provoked by her foreign, African accent in her interactions with Americans who would speak to her "too slowly as though to an idiot" (216). Instead of feeling resentful, however, Ifemelu, like her Aunty Uju, starts altering her accent and resolves to master the American accent and culture. And she, unlike many others, does succeed, as evidenced by the compliment she receives from an impressed telemarketer who cannot believe she can sound "totally American" in only three years (215).

Despite her successes in her assimilation path, however, Ifemelu realizes that no matter what, in a racialized America, she is black, as she later announces in the title of one of her blog posts, "To My Fellow Non-American Blacks: In America, You Are Black, Baby.” This not only marks her discovery of the race problem in America but also her recognition of the racial gap that will stand in her way of seamlessly assimilating in America. This significant disruption to harmonious assimilation marks the end of Ifemelu's first stage in her discovery of herself and its markers of identity that will eventually lead her to leave America and return to Nigeria. As she points out to Zemaye after her return to Nigeria, she "discovered race in America" (499). Explaining the same point in her debate with other characters about Post-racial America, Ifemelu says: "I came from a country where race was not an issue; I did not think of myself as black and I only became black when I came to America" (359). ${ }^{9}$ Ifemelu's discovery of her race in America, however, is not a simple recognition of her black race. Njubi Nesbitt elaborates on this more explicitly:

It is in exile that a Nigerian Igbo, South African Zulu, and Kenyan Kikuyu suddenly and unequivocally become Africans.... What exactly does it mean to be an African in Europe or the United States? One quickly learns that the answer is not pretty. It is written on the faces of obnoxious waitresses, the teacher who slams the door of opportunity, the policeman who treats you like a criminal. It is reflected in the floods of negative media images that poison people's minds with racist stereotypes. (71)

While every African immigrant in the West, at some point, must grapple with such an unpleasant discovery of the baggage attached to her black

9 In her interview with Boston Review, Adichie confesses that her experiences in America were very similar to those of Ifemelu. 'I'm very much like her [Ifemelu]. In Nigeria I didn't think of myself as black. I didn't need to. And I still don't when I'm in Nigeria. Race doesn't occur to me. Many other things occur to me. But in the United States, yes." 
race, for Ifemelu this marks an important turning point in her immigration journey in the US and the beginning of her Pan-African phase. Unlike her former assimilating self, during her Pan-African phase, Ifemelu no longer ignores or suppresses race. In fact, race becomes central to her oppositional identity. Instead of feeling stigmatized and belittled by her denigrated race in America, she proudly embraces it. This is not only apparent in her starting the Raceteenth blog with its sympathetic perspective on the problems faced by African Americans but also by her stopping to relax her curly hair and her relationship with her African-American partner Blaine.

Ironically, instead of easing her integration into American society, her biracial relationship with her extremely privileged white boyfriend Curt seems to have further revealed to Ifemelu the racial gap that separates her from mainstream white America. Although this relationship helped Ifemelu circumvent many of the hardships facing other African immigrants in legalizing their status and finding respectable and well-paying jobs, it also, she confesses later, fueled her consciousness of her difference, especially her blackness. As she explains in her outburst against a Haitian poet who declares "race was never an issue" in her relationship with her white partner, race may not be a problem between the partners in a biracial relationship but it "matters" as soon as the couple "step[s] outside" into the society (359). It seems that it is the recognition of the racial gap between herself and Curt's family and acquaintances, coupled no doubt with her discovery of his infidelity, that drives her to self-sabotage their relationship by sleeping with her neighbor. Incidentally, earlier in a short story entitled "The Thing Around Your Neck," Adichie had similarly depicted the biracial relationship of another female Nigerian immigrant in the US. While the relationship seems to have helped the anonymous protagonist better cope with her loneliness and anomie in the US, it also heightens her consciousness of her difference as a Nigerian and African, which is why the story ends rather ambiguously with the character leaving her partner and the US for Nigeria without specifying whether she will return or not.

Besides the contentious posts about racism and tribalism in the US on her blog, Ifemelu's newly adopted oppositional and Pan-Africanist attitude is evidenced in her heated arguments with white characters who hold stereotypical and denigrating views about Africa and African countries and cultures. One of these characters is Kelsey, a white patron at the salon where Ifemelu is getting a braid. Ifemelu reveals her anti-assimilation stance by 
describing the unsympathetic Kelsey as a "liberal."10 In Kelsey, the novel says, Ifemelu recognizes the self-contradictions of "liberal Americans" who would "copiously" criticize America but would "not like" immigrants to do so because America was "much better than wherever" they had come from (233). This jab at liberalism is important because it was the contradictions of liberal America that ultimately prompted Ifemelu to depart from her assimilating and cosmopolitan path and embrace Pan-Africanism instead. At this point, Ifemelu has not only abandoned the liberalism underlying her assimilating phase but also has become vocal about the contradictions of liberalism and liberals. ${ }^{11}$ This can also be seen in Ifemelu's detached and cold attitude toward Blaine's progressive colleagues at Yale.

Interestingly, during this scene, Kelsey starts an argument with Ifemelu about V.S. Naipaul's novel The Bend in the River. Kelsey praises the novel "as the most honest novel [she has] read about Africa" (233). Ifemelu, on the other hand,

did not think the novel was about Africa at all. It was about Europe, or the longing for Europe, about the battered self-image of an Indian man born in Africa who felt so wounded, so diminished, by not having been born European, a member of a race which he had elevated for their ability to create, that he turned his imagined personal insufficiencies into an impatient contempt for Africa. In his knowing haughty attitude to Africa, he could become, even if only fleetingly, a European. (233-34)

Importantly, the flaw in the hero of Naipaul's novel, Salim, according to Ifemelu's analysis here, is Eurocentric cultural alienation, a problem that she has come to detect in her earlier self as well. Ifemelu's Pan-African stance is also evident in her retorts to Laura's attempts to exploit the success story of African immigrants in America to confirm her racist views on African Americans. Instead of endorsing Laura's racist comparison be-

10 As Uday Mehta notes in Liberalism and Empire, the universal and individualistic premises of liberalism are likely to predispose its adherents to such judgmental and hierarchical conception of cultural differences. Liberals, according to Mehta, cannot help but to "compare and classify the world" in a language that cannot be "neutral" and "cannot avoid notions of superiority and inferiority, backward and progressive, higher and lower" (20-21).

11 It is important to note how Ifemelu develops a dual identity in her blog and in public due to the liberal contradictions she has encountered in the US. The cold and hostile reaction Ifemelu receives after giving her first diversity talk to a white audience in Ohio teaches Ifemelu to mask her opinions about race in public forums and only give voice to them in her blog posts. "The point of diversity workshops, or multicultural talks, was not to inspire any real change but to leave people feeling good about themselves" (377). 
tween the two groups, Ifemelu reminds her of the limitations and hurdles facing African Americans as a racial minority in a racist America to which many Africans in postcolonial Africa have been strangers: "Maybe," she tells Laura, "when the African American's father was not allowed to vote because he was black, the Ugandan's father was running for parliament or studying at Oxford" (207).

Besides openly vocalizing her Pan-Africanist views, Ifemelu, at this stage, learns to embrace her African appearance. This is especially evident in her decision to stop relaxing her hair. After graduating from college, she is continuously advised to "lose the braids and straighten [her] hair" to increase her chances of success at job interviews (250). She had already seen this practiced by her aspiring Aunty Uju who insists on relaxing her hair for professional settings involving white people. Having given in to this council, however, she is shocked by the ensuing pain and side effects. Consequently, she not only starts sporting an Afro but also uses her blog to encourage other black women to stop relaxing their hair. As the popularity of whitening creams and hair relaxers in African countries shows, appearance is an especially important arena when investigating the issue of Eurocentrism in non-Western societies. ${ }^{12}$ Internalizing the inferiority complex that is inherent in Eurocentrism will not only affect an individual's views of their culture and their people but also their perceptions of their bodies and appearances. As Ifemelu's biracial friend Ginika notes, her peers in Nigeria view her as pretty, simply because she has a lighter skin tone (67). Thus, it is significant that in unlearning her Eurocentric views, Ifemelu should stop relaxing her hair and insist on having a natural Afro hairstyle.

Finally, it is not surprising that Ifemelu's Pan-African phase should involve a romantic relationship with her African American partner Blaine who also happens to be actively involved in issues relating to racial equality and justice for African Americans. However, ironically, it is this relationship as well as the success of her Pan-African Raceteenth blog that reveals to her the gulf that separates her as a Nigerian or African immigrant from

12 This is an example of colorism which refers to intra-racism within non-white cultures and communities against people who are darker or less white. See among others Meeta Jha's The Global Beauty Industry: Colorism, Racism and the National Body, Kathy Russell-Cole, et al.'s The Color Complex: The Politics of Skin Color in a New Millennium, and these two edited volumes: Color Matters: Skin Tone Bias and the Myth of Post-Racial America, and Skin Deep: How Race and Complexion Matter in the "Color-Blind" Era. 
African Americans. As Blaine's older sister Shan rather rudely points out to Ifemelu, the popularity of her controversial posts on racial issues in America on Raceteenth seems to be tied to Ifemelu's detachedness as an African and her "writing from the outside" that enables her to not "really feel all the stuff she's writing about" and that is why she can blog provocatively about race and still be endorsed by the mainstream culture. This perceived detached attitude is also the cause of the last quarrel between Ifemelu and Blaine. Blaine is enraged to learn that Ifemelu attended a meeting in the history department with her African friend, professor Boubacar, rather than participating in the anti-racism protest he had organized on campus. Their relationship is ruptured irreparably after he accuses Ifemelu of not being "sufficiently furious because she was African, not African American" (428).

It is important to note that Ifemelu's failure in her Pan-African phase seems to be emblematic of the failure of the larger Pan-African movement in the latter half of the $20^{\text {th }}$ century. As Tunde Adeleke argues, "The demise of colonialism [in Africa] unfortunately also marked the beginning of the end of Pan-Africanism as a movement" (522).

Perpetrators of the ills plaguing [postcolonial] Africa and black America ... are fundamentally different. There is no basis for unity on the grounds of shared problems, challenges, and enemies as in the past. ... The problems may be similar, but the perpetrators, that is, the enemies, are not the same. Africans are being discriminated against, oppressed, denied basic human rights, killed, and maimed by fellow Africans (524).

After the independence of African countries from European colonial powers, in other words, the dominant issues facing Africans in postcolonial African societies have been quite distinct from the white racism as the major issue confronting Africans in diaspora, particularly African Americans. The divergent backgrounds, histories, cultures, and problems of these two different groups explain the differences they display in their attitudes toward and interactions with white people. This divergence in priorities and perceptions of problems, Adeleke argues, has resulted in Pan-Africanism being mostly reduced to a "rhetorical" gesture rather than a meaningful movement. It is important to note, however, that while Pan-Africanism may have failed as a meaningful political movement, as the novel shows, it involves a significant identity component for Africans and African diaspora that still makes it a resonant force. This is the point highlighted by Adichie herself who admits that like Ifemelu she also has come to believe in the importance of cultural and racial differences. "People dismiss race and say, 'We are all 
the same' - this is not true. I experience the world differently because I am female and because I am dark-skinned." Despites its final failure, Ifemelu's Pan-African phase plays an important part in her quest to salvage her Nigerian and African identity that had been damaged by her internalized Eurocentrism. While this phase reaches an impasse as she realizes the gap that separates her as an African immigrant from African Americans, it has resulted in significant and positive changes in her perceptions of African Americans and her own identity and appearance as a black person.

While Pan-Africanism leaves a positive and significant impact on Ifemelu's perceptions of her black identity, appearance, and African Americans, it nevertheless underscores the distinct particularity of her identity as an African and more specifically as a Nigerian. This is why after the failure of her Pan-African phase, she returns to and embraces her Nigerian identity. This new phase in Ifemelu's immigration journey is, above all, evident in her return to her Nigerian accent. As mentioned before, soon after her arrival in the US, Ifemelu is shocked to realize how, despite her mastery of English language and literature, she is still marked by her accent as a foreigner. As she remembers in hindsight, it is the humiliation involved in her interaction with the patronizing Cristina Tomas that had hardened her resolve to erase her foreignness by eliminating her Nigerian accent and mastering the American accent.

Ifemelu is not the only Nigerian or African character in the novel to pursue this path. The effort at hiding the African, Nigerian, foreign accent is also persistently put forth by Aunty Uju, particularly in her interactions with white people. Foreign accent, it should be noted, may indeed block aspiring African and Nigerian immigrants from professional success as we can see in Foreign Gods, Inc. where the highly educated Nigerian immigrant Ike has become a cab driver after the failure in finding jobs which he blames on his accent after he is told by one of the employers that his "credentials are excellent but the accent is crappy" (32). However, professional success is not the only reason in mastering the American accent, as Ifemelu discovers later. Worse than that is the desire to hide one's "inferior" identity and blend into the "superior" mainstream white society. It is Ifemelu's recognition of this feeling in herself after feeling pride on being complimented on sounding "totally American" that causes her dramatically sudden decision to "stop faking an American accent" (213). "Why was it a compliment, an accomplishment to sound American? ... She had won, indeed, but her triumph was full of air. Her fleeting victory had left in its 
wake a vast, echoing space, because she had taken on, for too long, a pitch of voice, and a way of being that was not hers," Ifemelu reflects (215-16). Returning to her Nigerian accent, she thinks: "This was truly her; this was the voice with which she would speak if she were woken up from a deep sleep during an earthquake" (216). She also notes the shame in one's identity in Aunty Uju's interactions with white people. On these occasions, Uju not only puts on a nasal American accent but also becomes a different person: "And with the accent emerged a new persona, apologetic and self-abasing. She was overeager with the [white] cashier" (133).

Although Ifemelu's return to her Nigerian accent, culture, and identity in the last phase of her immigration journey in the US helps her complete the recovery from her previously Eurocentric identity, it also further estranges her from the prevalent culture in the US. The more she embraces and underscores her Nigerian identity, the more she is isolated. Ifemelu notes such marginalization in the lives of other Nigerian immigrants in the US like Aunty Uju's former Nigerian partner, Bartholomew, who is devoted to his Nigerian identity and culture in exile and is actively involved in online forums on Nigerian politics:

He [Bartholomew] had not been back to Nigeria in years and perhaps needed the consolation of those online groups, where small observations flared and blazed into attacks, personal insults flung back and forth. Ifemelu imagined the writers, Nigerians in bleak houses in America, their lives deadened by work, nursing their careful savings throughout the year so that they could visit home in December for a week, when they would arrive bearing suitcases of shoes, clothes and cheap watches, and see, in the eyes of their relatives, brightly burnished images of themselves. Afterwards they would return to America to fight on the Internet over their mythologies of home, because home was now a blurred place between here and there, and at least online they could ignore the awareness of how inconsequential they had become. (143-144)

Besides the feeling of becoming "inconsequential" in the US as a Nigerian, Ifemelu is concerned by the identity problems experienced by Aunty Uju's son Dike, as a second-generation Nigerian in the US. Ifemelu is worried that America's racialized society coupled with the assimilating and raceblind bent of Aunty Uju's parenting and lifestyle in the US will lead to Dike growing up with a low self-esteem, ignorant and confused about his Nigerian, African heritage and black race. Dike's suicide attempt shows that these concerns are indeed well-justified. Aunty Uju's success in achieving a respectable job as a physician seems to have done little in helping her son Dike resolve his issues regarding race and identity in the US. Throughout 
the novel, there are several instances where Dike's desire to "just want to be regular" is thwarted due to his race and appearance (227). After Dike's suicide attempt, Aunty Uju justifies downplaying race in her parenting because she "didn't want him [Dike] to start behaving like these people and thinking that everything that happened to him is because he's black." She insists that Dike, like some of her white patients, must have been simply depressed to commit suicide. This, however, is contradicted by Ifemelu who explains that "his depression is because of his experience." "You told him what he wasn't but you didn't tell him what he was" (470). ${ }^{13}$

These concerns explain why Ifemelu's Nigerian phase in the US is marked by depression and anomie which she describes as "the cement in her soul". While she has become fluent in American culture at this stage, she cannot feel at home there and yearns to return to Nigeria, "where she was supposed to be, the only place she could sink her roots in without the constant urge to tug them out and shake off the soil" (7). Needless to say, the hope for a reunion with her first love, Obinze, in Nigeria is another strong factor that fuels Ifemelu's discontent in the US.

After returning to Nigeria, however, Ifemelu is struck both by its increasing Westernization and the discovery of her own Americanization. Having imagined a Nigeria that is distinctly different from the West, Ifemelu is at first dismayed by the fascination the West still holds for Nigerians. What is worse is the crudeness of the idea of West in Nigeria which at times is simply reduced to mechanization and automation. For example, Ifemelu is shocked to note the popularity of frozen chips among Nigerians. Frozen chips are popular not just because they are convenient but also because they are seen as more modern, stylish, and refined. "Real potatoes are backward for [them]," Obinze explains to Ifemlu (548). ${ }^{14}$ Obinze reminds her that for Nigerians, Westernization equals modernization and mechanization which are believed to enhance their standard of living. The prestige associated

13 On the confusion, tension and problems regarding identity and race faced by second-generation Nigerian youth in the US, see Janet Awokoya's "Identity Constructions and Negotiations Among 1.5- and SecondGeneration Nigerians: The Impact of Family, School, and Peer Contexts." Harvard Educational Review. Vol. 82. No. 2. Summer2012.

14 In "McDonald's in Beijing: The Localization of Americana," Yunxiang Yan offers similar observations: "In the eyes of Beijing residents, McDonald's represents Americana and the promise of modernization" (41). "A consequence of the powerful appeal of representing Americana is the conversion of McDonald's hamburgers and fries, ordinary daily fare in America, into precious and stylish foreign cuisine in Beijing" (73). 
with the West and Westerners among Nigerians is, in fact, profitably exploited by Obinze who is using his English friend Nigel to front as a white manager for his company to acquire better contracts. ${ }^{15}$ The shock of relentless Westernization in Nigeria is compounded by Ifemelu's own gradual discovery of her own Americanization. "And so she had the dizzying sensation of falling, falling into the new person she had become, falling into the strange familiar. Had it always been like this or had it changed so much in her absence" (475). Given her estrangement from American culture signified by her deliberate discarding of her American accent, Ifemelu's Americanization is not only baffling to her but also bemusing to her friends: "You are looking at things with American eyes. But the problem is that you are not even a real Americanah. At least if you had an American accent we would tolerate your complaining!" (475-476). Nevertheless, Ifemelu feels disoriented in Lagos and finds herself unmoved by the prevalent taste in aesthetics and fashion. Ifemelu reflects on this upon hearing her friend, Ranyi, challenge her verdict on the ugliness of the house of the owner of the Zoe magazine, Aunty Onenu.

"And what an ugly house," Ifemelu said. It was monstrous, with two alabaster angels guarding the gate, and a dome-shaped fountain sputtering in the front yard.

"Ugly kwa? What are you talking about? The house is beautiful.

"Not to me," Ifemelu said, and yet she had once found houses like that beautiful. But here she was now, disliking it with the haughty confidence of a person who recognized kitsch.

"Her generator is as big as my flat and it is completely noiseless!" Ranyinudo said. "Did you notice the generator house on the side of the gate?"

Ifemelu had not noticed. And it piqued her. This was what a true Lagosian should have noticed: the generator house, the generator size. (484-485)

Noting her own Americanization, Ifemelu tries fraternizing in a social group of Nigerian returnees from the West called the Nigerpolitan Club. While Ifemelu notes similarities between her own hybridized identity and those of other Nigerian returnees she meets in the Nigerpolitan Club, she is repelled by the predatory nature of their cosmopolitanism and their return to Nigeria.

15 For an intriguing fictional and satirical depiction of the prestige and fascination associated with the West and Westerners in general among Nigerians, see A. Igoni Barrett's Blackass. 
They do not seem to have returned to Nigeria out of love for its culture, heritage, and people but rather for exploiting opportunities that may be only available to them in a Westernizing Nigeria. This is why they don't balk at disdainfully criticizing various aspects of Nigerian culture and flaunting their own Westernized lifestyle and taste. "Their voices burned with foreign accents. You can't find a decent smoothie in this country! Oh my God, were you at that conference? What this country needs is an active civil society" (501). Repelled by the predatory cosmopolitanism on display by Nigerian returnees of the Nigerpolitan Club, Ifemelu resolves to downplay the dissonances in her hybridized, Americanized identity and look for ways she can restore her bond with Nigeria, its culture and people, hence her starting a new blog called The Small Redemptions of Lagos. This is why Ifemelu is "pleased to" have hear her friends tease her for her differences from other Americanahs i.e. pretentious Americanized Nigerian returnees (488).

By satirizing the Nigerpolitan Club, the novel seems to critique the notion of Afropolitanism which advocates a hybridized cosmopolitanism that is particular to African diaspora. In her essay on Afropolitanism called "Bye-Bye Babar," Taiye Selasi describes it as the mindset of African cosmopolitans or "Africans of the world," young Africans feeling at home in the world. According to Selasi, Afropolitans are "African young people working and living in cities around the globe ... [who] belong to no single geography, but feel at home in many."16 Thus she seeks to highlight the mobility and fluidity in multiple cultures and languages among the new generation of African diaspora in the increasingly globalized Western Europe and North America and their lack of attachment to a particular culture, locality and ethnicity. Americanah challenges such a positive perception of cultural hybridity and African cosmopolitanism by highlighting both the cultural problems facing African immigrants in Europe and North America and the predatory purposes for which such African cosmopolitanism could be abused. As Taylor argues, the conflicts and problems facing African immigrants arising from cultural and racial differences highlighted by the novel "demonstrate how cultural hybridity is founded on a break between cultural practices, not a smooth reconciliation of them" (75). In other words, a member of a minority culture or race in North America and Western Europe will have to downplay or erase traces of their cultures and 
identities to be successfully integrated into the host culture. In one of her interviews, Adichie expresses a similar ambivalence about cosmopolitanism:

I consider myself a Nigerian -- that's home, my sensibility is Nigerian.... I like America, and I like that I can spend time in America. But, you know, I look at the world through Nigerian eyes, and I am happiest when I am in Nigeria. I feel most - I question myself the least in Nigeria. You know, I don't think of myself as anything like a "global citizen" or anything of the sort. I am just a Nigerian who's comfortable in other places.

Besides ignoring the cultural difficulties facing African immigrants in the West, cosmopolitan perspectives like Afropolitanism could merely function as a façade for selfish and predatory purposes ${ }^{17}$ In his article on the persistence of colonial mentality and internalized racism and Eurocentrism in postcolonial Africa, M. E. Ochonu explains how "the cultural economy of trans-Atlantic travel and return is guided by an existing perceptual economy in which return from Western metropolis confer the vicarious honorifics of whiteness" (13). This is why, Ochonu explains, "Many beentos, Africans who have visited or lived in Europe or North America return to African homelands with exaggerated exhibitions of 'white' mannerisms and speech forms. A significant aspect of this performance is an attitude of affective snobbery towards compatriots, especially compatriots in lower socioeconomic and educational stations of life" (12). As the novel indicates, the cosmopolitanism on display by members of the Nigerpolitan club seems to have been reduced to an ostentatious display of "whiteness" and snobbery toward Nigerian cultural practices and norms. The problem in Africa, as the novel shows, is not lack of affinity with the West but rather the opposite; many people, especially the youth have become estranged from their cultures, societies, and people due to their infatuation with an idealized and imaginary West. The pervasive worshipful attitude toward Europe and European culture is evidenced further by the popularity of international schools among the Nigerian elite who use this as another means of showing off their wealth and class. This, however, is not ignored by the critical perspective of the novel that points out the incongruity of the snowy Christmas

17 For a critique of Afropolitanism as a hybrid identity for Africans in diaspora, see chapter 7 in Maximilian Feldner's Narrating the New African Diaspora: $21^{\text {st }}$ Century Nigerian Literature in Context. On Adichie's critique of Afropolitanism, see Jack Taylor's "Language, Race, and Identity in Adichie's Americanah and Bulowayo's We Need New Names." 
in a play set in Nigeria staged by one of these international schools for a Nigerian audience that has never witnessed snow during Christmas in Nigeria.

Importantly, the novel ends with Ifemelu's ex-Nigerian partner Obinze leaving his wife to restart his relationship with her. Just as Ifemelu's previous relationships with Curt and Blaine reflected her evolving identity in the US, her reunion with Obinze allegorizes her return to her Nigerian culture and identity. Besides love, what attracts Ifemelu to Obinze is their shared cultural heritage and understanding which would allow her to be "herself" without "the need to explain herself" (7). Ifemelu's cross-cultural romantic relationships in America with Curt and Blaine played an important role in heightening her consciousness of her differences as an African and a Nigerian. Ifemelu explains that in her "cross-cultural relationships," she spent so much time explaining that "sometimes [she] wondered whether we could even have anything at all to say to each other if we were from the same place" (563). Ifemelu's recovery of her relationship with Obinze is thus akin to her return to her Nigerian accent, her decision to stop relaxing her hair and her return to Nigeria. These changes not only declare her rediscovered pride in her native culture but also her recognition of the importance of living in that culture in expressing her authentic self. Having discovered the intimate relationship between culture and self, it is not surprising that one of Ifemelu's most important personal decisions, i.e. her future life with Obinze, should be influenced by the recognition of their shared culture. As Esplin argues, the reunion between Obinze and Ifemelu is "a definitive statement as to the value of ... not having to constantly translate or endure a setting or relationship that necessitates a sublimation of self and one's identity. [Adichie] invites and reiterates the idea that Ifemelu and Obinze are united and drawn back to each other because of their mutual desires for the kinds of freedoms and ready commensurability that they find in each other and, most abundantly, in Nigeria" (82). Thus, Ifemelu's reunion with Obinze can be read metaphorically as the last and perhaps most important part of her return to her Nigerian identity and culture. As Esplin argues, "though Obinze serves as a rather cardboard stand-in for the nation, the reconciliation between Ifemelu and Obinze can be read as a statement of national loyalty as much as the resolution of the relationship that frames the novel" (84). Depicting the economic and cultural problems facing its Nigerian immigrant protagonists, Chimamanda Ngozi Adichie's novel, Americanah provides a great opportunity for its readers to understand the radical changes in the perceptions of immigrants both of their own culture and that 
of the Western society to which they immigrate. It shows how the racism, isolation and anomie experienced by immigrants compel even alienated individuals who previously idealized the West to embrace their cultures and identity. Focusing on the US context, the novel shows the effects of racialization on African immigrants and explores the variety of identity positions and coping mechanisms they may have recourse to including assimilation, Pan-Africanism, and a hybrid Nigerian-American identity. Having unsatisfactorily experimented with all these positions, Ifemelu decides to leave America altogether and return to Nigeria where she, ironically, discovers the variety of ways in which she has been unwittingly Americanized by her stay in the US. Having discovered the importance of her bond with her Nigerian culture to her identity and self-esteem, however, Ifemelu resolves not to become another Americanah and to downplay the Westernized aspects of her identity and merge into her surroundings in Nigeria. By frankly depicting the radical changes undergone by immigrants after their immigration to the West, Americanah could help us understand the surprising turn to cultures and away from liberalism at the start of the twenty-first century. 


\section{Works Cited}

Adeleke, Tunde. "Black Americans and Africa: A Critique of the Pan-African and Identity Paradigms" The International Journal of African Historical Studies. 1998. 31.3: 505538.

Adichie, Chimamanda Ngozi. Americanah. Anchor Books, 2013.

---. The Thing Around Your Neck. Alfred. A Knopf, 2009.

---. We should All Be Feminists. New York: Anchor Books, 2014.

Arthur, John A. Invisible Sojourners: African Immigrant Diaspora in the United States. Westport, Connecticut: Praeger, 2000.

Austin, Patrycja. "Searching for One's Self at the Crossroads of the Cosmopolitan World: Determining the Importance of Roots for Those Who Travel through Diversities in Chimamnda Ngozi Adichie's Americanah" Ostrava Journal of English Philology 7.1 (2015): $7-16$.

Awokoya, Janet. "Identity Constructions and Negotiations Among 1.5- and Second-Generation Nigerians: The Impact of Family, School, and Peer Contexts". Harvard Educational Review. Vol. 82. No. 2. Summer2012.

Barrett. A. Igoni. Blackass: A Novel. Graywolf Press, 2016.

Bady, Aaron, and Chimamanda Ngozi Adichie. "The Varieties of Blackness" Boston Review. July 10, 2013.

Bulawayo, NoViolet. We Need New Names: A Novel. Little, Brown and Company, 2013.

Chakrabarty, Dipesh. Provincializing Europe: Postcolonial Thought and Historical Difference. Princeton UP, 2000.

Durkheim, Emile. Suicide: A Study in Sociology. Trans. John Spaulding and George Simpson. New York: Free Press, 1979.

Esplin, Marlene. "The Right Not to Translate: The Linguistic Stakes of Immigration in Chimamanda Ngozi Adichie's Americanah." Research in African Literatures 49.2 (2018): 73-86.

Fanon, Frantz. Black Skin, White Masks. Trans. Richard Philcox. 1952. New York: Grove Press, 2008.

---. The Wretched of the Earth. Trans. Richard Philcox. New York: Grove Press, 2004.

Feldner, Maximilian. Narrating the New African Diaspora: 21 st Century Nigerian Literature in Context. Palgrave, 2019.

Gikandi, Simon "Foreword: On Afropolitanism." Negotiating Afropolitanism: Essays on Borders and Spaces in Contemporary African Literature and Folklore. Ed. Jennifer Wawrzinek and J. K. S. Makokha. Amsterdam: Rodopi, 2010. 9-11

Herbert, Christopher. Culture and Anomie: Ethnographic Imagination in the Nineteenth Century. Chicago: Chicago University Press, 1991.

Herring, Cedric, Verna Keith and Hayward Horton, eds. Skin Deep: How Race and Complexion Matter in the "Color-Blind" Era. University of Illinois P. 2004.

Jha, Meeta, The Global Beauty Industry: Colorism, Racism and the National Body. New York: Routledge, 2016.

Kellaway, Kate, and Chimamanda Ngozi Adichie. "Chimamanda Ngozi Adichie: 'My New Novel Is about Love, Race... and Hair'.” The Guardian, 6 Apr. 2013. 
Levi-Strauss, Claude. The View From Afar. Trans. Joachim Neugroschel and Phoebe Hoss. Chicago: Chicago University Press, 1992.

Mbue, Imbolo. Behold the Dreamers. Random House, 2016

Mehta, Uday Singh. Liberalism and Empire: A Study in Nineteenth-Century British Liberal Thought. Chicago: Chicago University Press, 1999.

Ndibe, Okey. Foreign Gods, Inc. Soho. New York, 2014.

---. Never Look an American in the Eye: Flying Turtles, Colonial Ghosts, And The Making of a Nigerian American. Soho. New York, 2016.

Nesbitt, F. Njubi. "African Intellectuals in the Belly of the Beast: Migration, Identity, and the Politics of Exile.” African Issues 30.1 (2002): 70-75.

Ngũgĩ wa Thiong'o. Decolonising the Mind: The Politics of Language in African Literature. 1986. James Curry, 2003.

Norwood, Kimberly Jade. Color Matters: Skin Tone Bias and the Myth of Post-Racial America. New York: Routledge, 2014.

NPR staff and Chimamanda Ngozi Adichie. “A Nigerian-'Americanah' Novel About Love, Race And Hair" NPR. May 11, 2013.

Ochonu, Moses E. "Looking for Race: Pigmented Pasts and Colonial Mentality in 'Non Racial' Africa" Relating Worlds of Racism: Dehumanization, Belonging, and the Normativity of European Whiteness. Ed. Philomena Essed et al. Palgrave, 2019.

Oguine, Ike. A Squatter's Tale. Oxford: Heinemann, 2000.

Okin, Susan Moller. "Is Multiculturalism Bad for Women?" Is Multiculturalism Bad for Women? Ed. Joshua Cohen, Matthew Howard and Martha Nussbaum. Princeton: Princeton UP, 1999. 7-26.

Pyke, Karen. "What is Internalized Racial Oppression and Why Don't We Study It? Acknowledging Racism's Hidden Injuries.” Sociological Perspectives 53.4 (2010): 551575.

Selasi, Taiye. 2005. "Bye-Bye, Babar (Or: What Is an Afropolitan?)". The LIP Magazine. http://thelip.robertsharp.co.uk/?p=76. Accessed 15 Mar 2020.

Shohat, Ella and Robert Stam, eds. Unthinking Eurocentrism: Multiculturalism and the Media. New York: Routledge, 1994.

Taylor, Charles. "The Politics of Recognition." Philosophical Arguments. Cambridge, MA: Harvard UP, 1995. 225-256.

Taylor, Jack. "Language, Race, and Identity in Adichie's Americanah and Bulowayo's We Need New Names." Research in African Literatures 50.2 (2019): 68-85.

Wagner, Roy. The Invention of Culture. Revised Ed. Chicago: Chicago UP, 1981.

Williams, Raymond. Key Words: A Vocabulary of Culture and Society. Revised Ed. Oxford UP, 1986.

Yunxiang Yan "McDonald's in Beijing: The Localization of Americana" Goldern ArchesEast: McDonald's in East Asia. Ed. James Watson. Stanford UP, 1997. 38-76. 